\title{
Review of Mount Olympus: to Glorify the Cult of Tragedy
}

Play directed by Jan Fabre, performed in Belgrade

September 182017

Review by Sandra Dančetović*

Translated by Rastko Novakovic and Sanja Milojevic

Address

*Correspondence: [sandra.dancetovic@gmail.com]

\section{Breathe freely and imagine something new - Mount Olympus}

To understand Belgrade you do not need to live here. It is difficult for ourselves, its inhabitants, to make ourselves out in its numerous contrasts. You will notice the contradictions at every step: from the city's appearance, its architecture which is a fusion of the old and the new, the Ottoman and the Austro-Hungarian, the European and the Balkan, the Western and the Eastern, to the profound divisions in society and inconceivable contrasts, such as a pronounced nationalism on the one

(C) Copyright: The Authors. This article is issued under the terms of the Creative Commons Attribution NonCommercial Share Alike License, which permits use and redistribution of the work provided that the original author and source are credited, the work is not used for commercial purposes and that any derivative works are made available under the same license terms. hand and unwavering cosmopolitanism on the other.

With these contrasts and divisions in mind, we can more easily - but never completely - understand the city which gave birth to BITEF (an international festival of theatre, which has existed for half a century and was founded by Mira Trailović, one of the greatest women in the history of Yugoslav culture) and the city which met one of the best theatre performances of 2017, with extreme hostility.

This is what happened to 'Mount Olympus' by the Belgian director Jan Fabre, which opened the $51^{\text {st }} \mathrm{BITEF}$ in September 2017. This European 
theatrical hit, a performance which was created 'to glorify the Cult of Tragedy', as its subtitle suggests, caused waves of disapproval, indignation and even disgust in Belgrade and Serbia.

The script for 'Mount Olympus' (by Jeroen Olyslaegers and Fabre himself) combines and develops dozens of texts from ancient Greece, including Homer's epics, Greek tragedies and myths. This new, composite script offers a fresh reading of ancient and well known texts. The play features thirty actors who dance, speak, perform acrobatics, repeat a single action endlessly. Given that the play runs for 24 hours continuously, the performers also sleep and suffer from sleep deprivation, examining their outer physical and mental limits. On the stage we saw performers suffer, weep, laugh hysterically, make celebrations, despair, fall into trances, dance wildly, make love, strip, pour oil, paint and glitter over each other... The sight of a naked body tested to the extremes, caused shock in many spectators; even though none of the staged actions were performed gratuitously, but were filled with layers of meaning, which evaded those whose gaze remained only on the surface.

The performance was featured on TV, in a live broadcast and on a public service station. Thus, a much wider audience could access a twenty-fourhour spectacle, otherwise limited to the 2,000 people attending the 'Sava Centre' hall. According to official data from the Radio-Television of Serbia (RTS), more than 220,000 people tuned in for the finale of the broadcast. Afterwards, television viewers moved onto social media, where a war of words erupted about the show and a public service provider that broadcasts 'obscene nudity' and 'pornography'. The Twitterati were horrified by the naked actors, and saw the Dionysian festivities on the stage as mere 'rope skipping', comparing the show with reality TV programmes. 
According to ratings, 'Mount Olympus' actually overshadowed reality programmes, at least for 24 hours. Art occupied a space reserved for the basic instincts of Serbian, (dare I say) pop 'un-culture', since the reality TV format, in its lowest and basest form, is currently the most popular in Serbia.

'Mount Olympus' achieved what, according to Kafka, is the task of art - to be the axe for the frozen lake in our souls. It wore out both the performers and the spectators, throwing both into a trance.

Together they breathed, collapsed, slept. It fulfilled the main task of ancient tragedy - catharsis.

While some were affronted by the 'obscene nudity' of the human body and symbols which they misunderstood as pornography, it seemed that in the end, the experience of that other part of the audience seemed to prevail: the show left the nearly 2,000 people in the hall and a large section of those in front of the TV screen exhilarated. When the dust settled, favourable impressions prevailed, and 'Mount Olympus' was justly awarded the BITEF Grand Prix. The polarisation of the audience however, was evident and expressed in extremes typical for Belgrade and Serbia.

It seems that many spirits were calmed by the Facebook post of a church official, who, to widespread surprise and breaking with the traditions of the Serbian Orthodox Church, was reasonable. On his Facebook profile, deacon Nenad Ilić, himself a trained theatre director, wrote that he had not seen 'a product of contemporary art that could command such respect' in a long time, adding that 'a heroic effort was made not to recognise the death of art'. What surprised and silenced those who 
criticised'Mount Olympus' without foundation was Ilić's statement that the recording of the performance should be screened 'if not in seminaries, then definitely at theological faculties, in order that future priests and theologians could in time find the real answer to the scream of our times: Give us something truly new!'

Ilic saw the play as a call to dialogue, a sincere and authentic look at modern society, which is not without humour and vitality although at its core is tragedy and wo/man as a tragic hero. The direct and explicit message of the play is: 'Breathe freely and imagine something new!' So simple, clear to understand and yet difficult to apply. Especially in a society in which church officials have the last word - even if they are right, which rarely happens. The example of deacon Ilić is only an exception that proves the rule.

Blinkered faux moralists were calmed only by the words of a church official, regardless of the fact that prominent theatre experts, such as the playwright Biljana Srbljanović, interpreted the show along similar lines.

It is therefore unsurprising that just a few weeks later there was widespread support for another church official, this time in making disgusting misogynist remarks. Bishop Amfilohije, otherwise known for his nationalistic, homophobic, misogynist and generally discriminatory outbursts, stated thatSerbian women who undergo abortion 'kill more children in a year than Hitler and Mussolini'; thereby comparing abortion with infanticide, and women who decide on their bodily integrity and reproductive health with Nazis and fascists. 
As a rule, those facing the worst discrimination (women, the LGBT+ community, anti-nationalists, members of minority peoples and religious groups) are at the receiving end of church officials.

The words of Amfilohije were taken up and expanded upon by the head of the Serbian Orthodox Church, Patriarch Irinej, who said that women must bear children. 'We are duty-bound to renew our people and to recommend to our mothers that they are obliged to bear children according to God's blessing; in that way we will remain a part of history, even though we have perished greatly.' said the Patriarch.

Such shameless statements did provoke negative public reactions, even from a female minister in the government Zorana Mihajlović. She responded to the Patriarch that women decide on their own lives and that his advice is unnecessary. However, it seems that Serbian society is not mature or bold enough to uncompromisingly oppose hate speech, especially when it comes from church officials.

Hence, we are not surprised by the reactions of many viewers to the show 'Mount Olympus'. When people intimidated by the church, the state, their neighbours and their surroundings, suddenly see before themselves (on the stage or on television) a demonstration of freedom, honesty, authenticity, true art, and joie de vivre, it is difficult for them to cast away the shackles imposed by fear of authority.

\section{To cite this article:}

Dančetović, S. (2018). Review of Mount Olympus: To Glorify the Cult of Tragedy, a play directed by Jan Fabre. Feminist Dissent, (3), 265-269. Retrieved from: https://journals.warwick.ac.uk/index.php/feministdissent/index 